\title{
ENHANCING SUSTAINABILITY AND FODDER PRODUCTION OF LOWLAND PASTURES THROUGH FENCING AND CONSERVATION AGRICULTURE IN ARID AGRO-PASTORAL ECOSYSTEMS
}

\author{
Tlili, A. ${ }^{1}$ - Fetoui, M. ${ }^{2}$ - Ben SAlem, F. ${ }^{1}$ - LOUhaichi, M. ${ }^{3}$ - Neffati, M. ${ }^{1}-$ TARHOUni, M. $^{1 *}$ \\ ${ }^{1}$ Institut des Régions Arides. Laboratoire des Ecosystèmes Pastoraux et Valorisation des \\ Plantes Spontanées et des Microorganismes Associés, University of Gabes, 4100 Médenine, \\ Tunisia
}

${ }^{2}$ Institut des Régions Arides, Laboratoire d'économie et Sociétés Rurales, University of Gabes, 4100 Médenine, Tunisia

${ }^{3}$ International Center for Agricultural Research in the Dry Areas (ICARDA), Tunis, Tunisia

\author{
${ }^{*}$ Corresponding author \\ e-mail: medhtarhouni@yahoo.fr \\ (Received 15 $5^{\text {th }}$ Mar 2021; accepted 30 ${ }^{\text {th }}$ Aug 2021)
}

\begin{abstract}
The short-term fencing effects on vegetation in dryland landscape depressions are analyzed and the economic performance of grazing-only and integrated grazing with cropping in regard to land capital are compared. The goal is to suggest efficient strategic choices and more profitable land allocation of lowlands in dry areas. To analyze the vegetation, 12 cages each $2 \mathrm{~m}^{2}$ were installed at three sides of a depression (4 east, 4 middle and 4 west side). Natural vegetation was recorded in the inside and outside cages during the spring of 2015, 2016 and 2018. Pastoral productivity was also calculated. To study the economic performance of cropping systems, local owner-farmers representing three cropped areas $(1,3$ and 9 ha) were interviewed using socioeconomic surveys. The main results showed that short-term fencing increased diversity (24\% to $61 \%$ in the middle cages). This improvement is due to annuals and the recruitment of palatable perennials. Economic evaluation showed that grazing is more profitable than integrated management, except for diversified and large cropped areas. The strategic recommendations for efficient, profitable and sustainable lowland allocation are short-term fencing with grazing-only in small depressions, and diversified crops mixed with grazing in larger depressions.
\end{abstract}

Keywords: rangeland management, economic performance, drylands, landscape depressions, Marab

\section{Introduction}

During the last few decades, climate change and overexploitation have destroyed natural resources and dramatically changed many ecosystem services (Vijaya Venkataraman et al., 2012; Hoffmann et al., 2014). Impacts on ecosystems can be environmental, economic and social, particularly in the most vulnerable semi-arid and arid areas (Schilling et al., 2012; Grimm et al., 2013). In these areas, ecological balance has been destabilized by human pressure and changes in land use and abiotic stresses, consequently affecting biodiversity and resilience capacity (Aïdoud et al., 2006; Eskandari et al., 2016; Zhang et al., 2016). Despite their fragility, these large areas are occupied by almost $38 \%$ of the world's human population. They contribute to carbon sequestration, combat desertification, and maintain livestock farming (Lal, 2002; Reynolds et al., 2007). Apart from its position in the food chain as the primary producer, spontaneous vegetation plays an important role in the prevention of soil degradation and erosion, maintenance of soil structure and fertility, and regulation of water flows and 
climate (Alcamo, 2003; Hoffmann et al., 2014). Many natural ecosystems are disturbed following their conversion to farmland and selective exploitation. Grazing, animal breeding and seasonal cropping are the main agricultural activities affecting dryland ecosystems. These land uses have changed during recent decades due to intensification and increases in productivity, following changes in human population density and progress in cultivation techniques, mechanization and agrichemicals. Overgrazing occurs in some localities when the stocking rate is exceeded, and rangeland availability is reduced by plowing or water deficits (Ouled-Belgacem et al., 2013). Hence, human activities and poor land management, particularly overgrazing, exacerbated by climate change constitute the main causes of ecosystem degradation (FAO, 2006; Tietjen and Jeltsch, 2007; Carmona et al., 2013; Hoffmann et al., 2014).

To avoid this decline, strategic management, conservation techniques and sustainable use should be pursued. Various solutions have been developed to preserve pastoral areas in Southern Tunisia, with a focus on rehabilitation and pastoral enhancement techniques and interventions. Fencing is one of the most well-known and traditionally widely practiced techniques for rangeland management in Tunisia and elsewhere around the world (Nefzaoui and Mourid, 2008; Squires et al., 2009; Gamoun et al., 2018; OuledBelgacem, 2018).

This technique, locally known as gdel, consists of leaving part of a rangeland to rest (without grazing) for a period of two to four years depending on the ecosystem capacity to recover and rainfall conditions, to reconstitute plant cover, reduce soil erosion and increase fodder production, soil organic matter , and biodiversity (Ouled-Belgacem, 2012). Landscape depressions, known as marab in Arabic, constitute one of the betterintegrated agro-pastoral systems with good edaphic and hydrologic properties. These agro-pastoral systems bring together the agricultural activities of grazing and cropping.

However, instabilities shaped by these activities can lead to disturbed vegetation structure, principally revealed by a decline in perennial plants (Hubbell et al., 1999; Slimani and Aïdoud, 2004). Several approaches to local management have been applied to reduce degradation by enhancing some marginalized resources (e.g., revegetation using pastoral halophytes and alternative feeds in scarce seasons) and re-adjusting the ecological balance (Temel et al., 2015; Ayeb et al., 2016; Tlili et al., 2018).

To mitigate ecosystem degradation and reduce forage deficiency requires improving our knowledge of the specificities of agro-pastoral systems. Furthermore, the grazing and cropping combination must be analyzed to show the environmental impacts and economic efficiency. In this context, the present work aims to assess free grazing and fencing impacts on natural vegetation and to compare the economic performance of grazing-only and integrated grazing with cropping to suggest optimal choices and more profitable and sustainable land allocation for arid lowland depressions.

\section{Materials and Methods}

\section{Study site}

The study was in the Samaliete region, southern Tunisia $\left(33^{\circ} 18^{\prime} 08.26^{\prime \prime} \mathrm{N}\right.$, $10^{\circ} 55^{\prime} 30.11^{\prime \prime} \mathrm{E}$; Figure 1). It is characterized by an arid Mediterranean climate with high temperature variability and precipitation patterns. The mean annual precipitation is about $165 \mathrm{~mm}$ with an average annual temperature of $21.4^{\circ} \mathrm{C}$ (according to climate data for the period 1991-2016; https://climateknowledgeportal.worldbank.org). The rainiest months are December and January and the driest are June and July. Soils in this region are 
calcareous with gypsic materials in the surface. Skeletal-gypsic soils are found in the surrounding areas, but the middle of depressions are characterized by deep, sandy soil. Some dwarf shrubs (e.g. Gymnocarpos decander Forssk. and Anthyllis henoniana Coss. Ex Batt.), forbs and grasses dominate the natural vegetation cover of the region.

Historically, the region has been devoted to grazing sheep and goats with some cultivated field crops during rainy years (cereals and legumes).

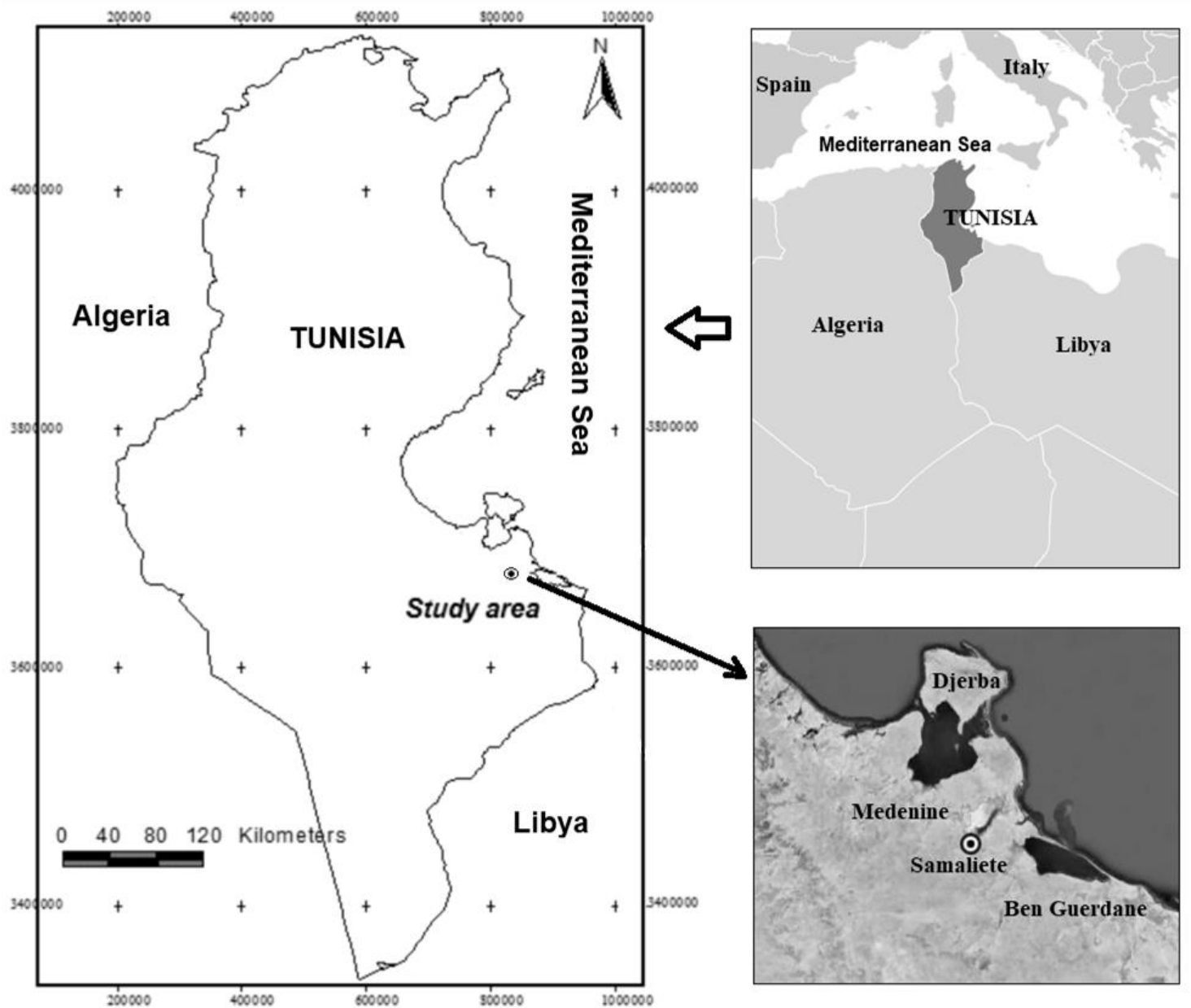

Figure 1. Geographical location of the study site

\section{Experimental design}

The experimental protocol was established on three sides of one lowland depression (east, middle and west side) in March 2015 (spring). The east and west sides of the depression were sloping (10\%) but the middle was flat (about $50 \mathrm{~m}$ width, cropped area). On each side, four replicate-rectangular cages (each $50 \mathrm{~cm}$ high, $2 \mathrm{~m}^{2}$ area and $15 \mathrm{~m}$ apart) were installed to protect vegetation from grazing animals, including small rodents (Figure 2 , Figure 3). Four other rectangular quadrats $\left(2 \mathrm{~m}^{2}\right.$ each, control) were installed and kept open to free grazing. Some ecological indicators such as flora richness and density were monitored during the springs of 2015, 2016 and 2018 inside and outside the cages. 

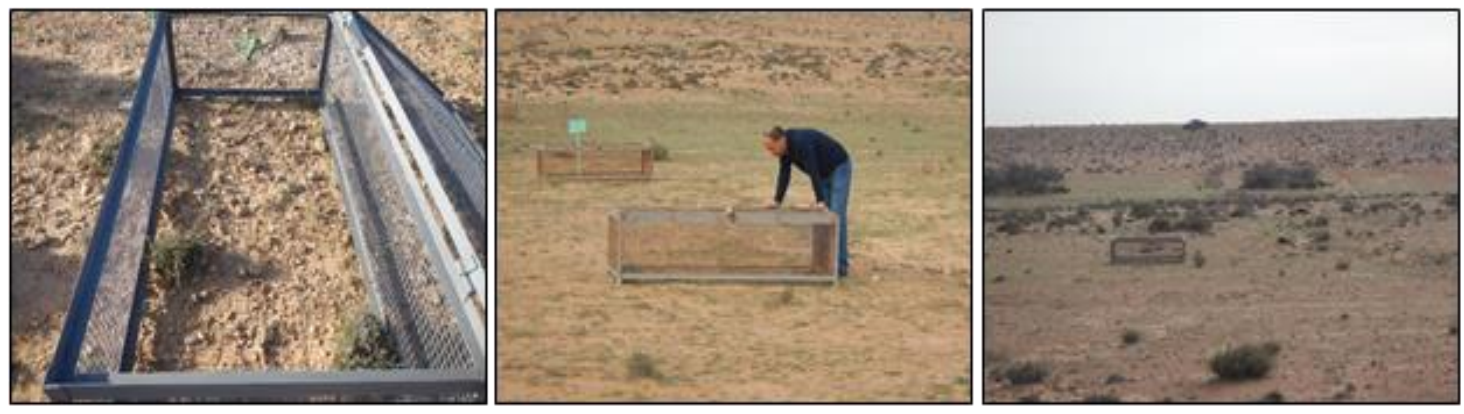

Figure 2. Cage design and the overall view of the experimental depression

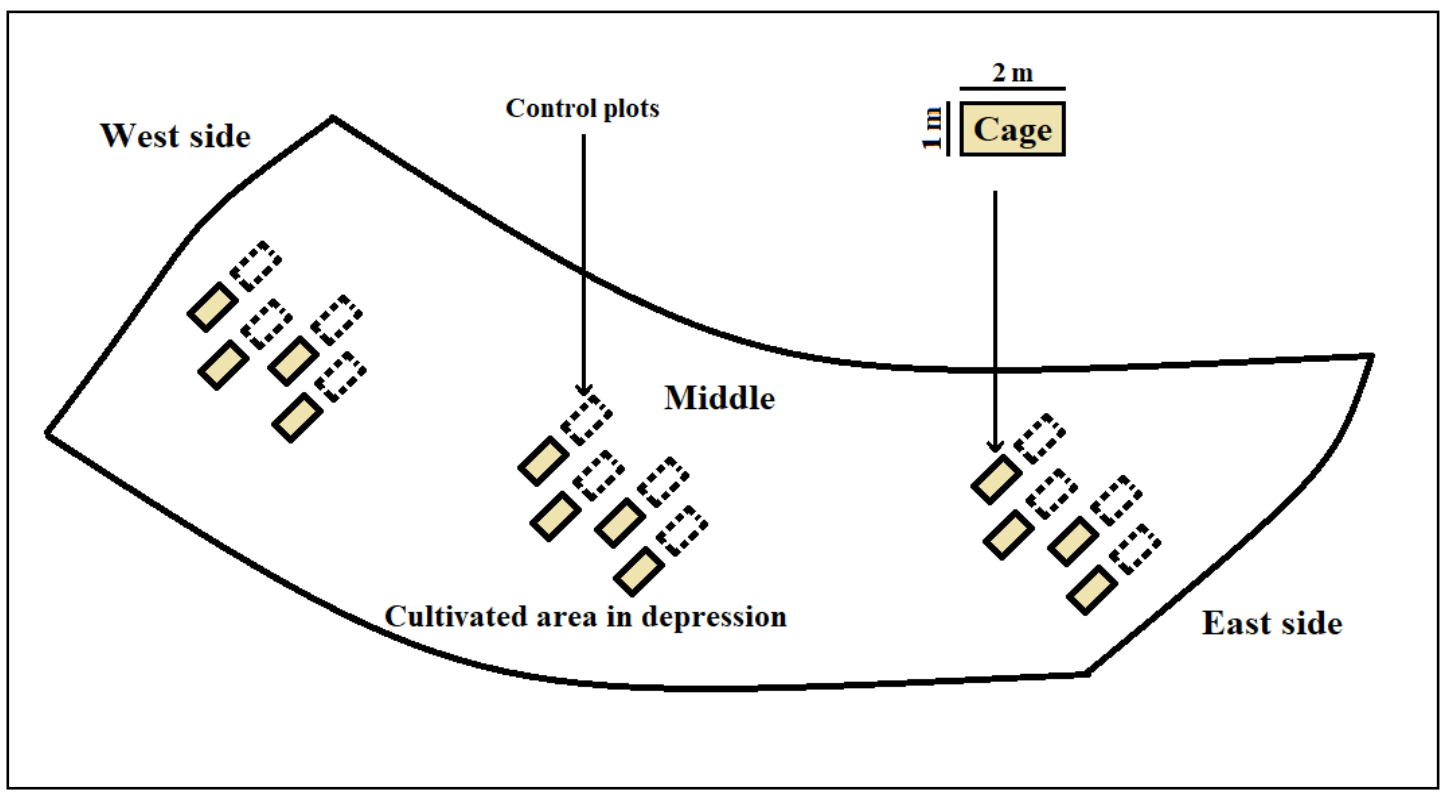

Figure 3. Cage locations and experimental design for the vegetation measurement in the west, middle and east sides of the studied depression

\section{Vegetation monitoring}

The grazing value (i.e. pastoral production) measurements were taken during the spring of 2015, 2016 and 2018, using the quadrat point method as described by Daget and Poissonnet (1971) and Floret (1988). Four lines (20 m length each) were monitored on each side of the depression. Every $20 \mathrm{~cm}$ along the tape, a fine pin was inserted in the ground and all vegetation and ground contacts were noted. In parallel, inside and outside cages, flora richness and density of perennial and annual species were evaluated, on each aspect/side during the study periods (Table 1).

The majority of plant species were identified in the field, and samples of unidentified species were collected and identified in the laboratory using reference books and taxonomic databases. Plant diversity between the monitored plots (Table 1) was determined using Jaccard's similarity index $\left(S_{J}\right)$ as described by Roux and Roux (1967) (Eq. 1). 
Table 1. Respective codes of the monitored plots within the depression over seasons

\begin{tabular}{c|c|c|c}
\hline Codes & Aspects/Sides & Grazing treatments & Spring of \\
\hline EO1 & East & Outside & 2015 \\
EO2 & East & Outside & 2016 \\
EO3 & East & Outside & 2018 \\
MO1 & Middle & Outside & 2015 \\
MO2 & Middle & Outside & 2016 \\
MO3 & Middle & Outside & 2018 \\
WO1 & West & Outside & 2015 \\
WO2 & West & Outside & 2016 \\
WO3 & West & Outside & 2018 \\
EI1 & East & Inside & 2015 \\
EI2 & East & Inside & 2016 \\
EI3 & East & Inside & 2018 \\
MI1 & Middle & Inside & 2015 \\
MI2 & Middle & Inside & 2016 \\
MI3 & Middle & Inside & 2018 \\
WI1 & West & Inside & 2015 \\
WI2 & West & Inside & 2016 \\
WI3 & West & Inside & 2018 \\
\hline
\end{tabular}

$$
S_{J}(x, y)=\frac{c}{(a+b-c)}
$$

where $a$ is the number of species in cage $x, b$ is the number of species in cage $y$ and $c$ is the number of common species between $x$ and $y$. The vegetation cover $(V C)$ was:

$$
V C=\frac{n}{N} \times 100
$$

With $n$ the number of hits of all plant species and $N$ the total number of hits. Thereafter, specific frequency of presence $(S F P)$ was calculated as:

$$
S P F_{i}=\frac{n_{i}}{N} \times 100
$$

With $n_{i}$ the number of hits of the $i^{\text {th }}$ species. The specific contribution of presence $(S C P)$ of $i^{\text {th }}$ species was:

$$
S C P_{i}=\frac{S F P_{i}}{\sum_{i=1}^{n} S F P} \times 100
$$

The grazing value $(G V)$ was then calculated:

$$
G V=0.2 \times \sum_{i=1}^{n}\left(S C P_{i} \times I s_{i}\right) \times V C
$$


where $I s_{i}$ is the acceptability index of $i^{\text {th }}$ species (Le Houérou and Ionesco, 1973). Finally, pastoral productivity $(P)$ was obtained according to Aïdoud et al. (1983):

$$
\boldsymbol{P}\left(\mathrm{FU} \mathrm{ha}{ }^{-1} \text { year }^{-1}\right)=\mathbf{7 . 5 2} \times \boldsymbol{G} \boldsymbol{V}
$$

where $\mathrm{FU}$ is the forage unit, (one $\mathrm{FU}$ is the equivalent of $1 \mathrm{~kg}$ of barley).

\section{Socioeconomic surveys}

The field investigations were coupled with socioeconomic surveys with four owners of neighboring cropped depressions. Only these four owners are still in the region due to rural exodus. The objective of the surveys was to evaluate owner incomes (cropped systems) in comparison with owners only grazing. The four evaluated crops were barley (1 ha), barley and lentil (both in $1 \mathrm{ha}$ ), barley and lentil (both in $3 \mathrm{ha}$ ) and barley, wheat and lentil (all in 9 ha).

Interviews were conducted by the research team during the spring of 2015 (rainy year, $167.8 \mathrm{~mm}$ ) and 2016 (dry year, $61.9 \mathrm{~mm}$ ). The questionnaire had four sections: (i) household demographic information, (ii) agricultural systems, (iii) farm economic analysis and, (iv) community-identified problems assessment. Each interview lasted on average 1 hour. The data was coded and cleaned using Excel and data analysis was carried out using SPSS software.

\section{Economic evaluation}

Annual grazing incomes of 1 ha depressions $(G I)$ in rainy and dry years (respectively 2015 and 2016) were calculated as:

$$
G I=P \times 0.14
$$

where 0.14 is the local price of $1 \mathrm{~kg}$ of barley (in Euro).

After crop harvesting during the rainy year (2015), the economic benefits from small ( $1 \mathrm{ha}$ ), medium ( $3 \mathrm{ha}$ ) and large (9 ha) plowed depressions were calculated. The economic efficiency and profitability of land allocation in four different lowland systems were then evaluated, taking into account the land capital (i.e. small, medium and large plowed areas), the crop diversification and the land allocation (i.e. grazed and cropped lands).

To investigate the economic performance and efficiency of each surveyed lowland farm, a set of economic indicators were calculated. These indicators were (i) total rainfed crop gross product, total cost (i.e. input and labor costs) and overall gross margin (crop income), (ii) efficiency of the production process (EPP) (gross product-inputs/gross product), to assess the overall economic efficiency of each farm, and (iii) the total income for the integrated crop and grazing systems for a period of four years. Note that in southern Tunisia the long-term frequency of rain is about 1 rainy/ 3 dry years per fouryear period (Ouessar et al., 2006). The total incomes for the grazing-only systems for four years were calculated to assess the profitability of the different farming systems and to identify more profitable land allocation. 


\section{Statistical analysis}

After testing normality (Shapiro-Wilk test) to verify homogeneity of variance, means were log-transformed. One-way ANOVAs were performed to separately compare density, richness and productivity under grazing, aspects and years effect. Two-way and three-way ANOVAs were used to test the interactions of these factors. Diversity analysis was carried out using the Jaccard similarity index between cages. All statistical analyses were performed using SPSS 20.0 software.

\section{Results}

\section{Flora richness}

The number of annual and perennial species in the inside and outside cages are presented in Table 2. The highest number of annuals was found in the middle of the depression $(16.3 \pm 3.4$ species $)$ and on the eastern side for perennials $(9.8 \pm 2.1$ species $)$. The lowest number of annuals occurred in spring 2016 inside cages on the east side of the depression, with $6.5 \pm 2.5$ species. During this same season, $4 \pm 1.2$ perennial species were found in the outside cages on the western side. In general, annuals were dominant in the inside and outside cages compared to perennials. Only annual forbs on the eastern side of the depression showed a significant difference $(\mathrm{F}=6.41 ; p<0.05)$ between outside $(10 \pm 3.6)$ and inside cages $(5.3 \pm 2.1)$, in spring 2016. The highest number of shrubs was on the east side of the depression and the lowest in the middle. This was due to plowing effects.

Table 2. Flora richness of inside and outside cages in the Samaliete depression during the spring of 2015, 2016 and 2018

\begin{tabular}{c|c|c|c|c|c|c|c}
\hline \multirow{2}{*}{} & \multirow{2}{*}{ Spring } & \multicolumn{3}{|c|}{ Inside } & \multicolumn{3}{c}{ Outside } \\
\cline { 3 - 7 } & & East & Middle & West & East & Middle & West \\
\hline \multirow{2}{*}{ Annual } & 2015 & $10.3 \pm 6.3$ & $13.5 \pm 2.7 \mathrm{~A}$ & $10.5 \pm 3.1$ & $9.8 \pm 2.2 \mathrm{~A}$ & $13.3 \pm 2.6$ & $11.0 \pm 3.6 \mathrm{~A}$ \\
forbs & 2016 & $5.3 \pm 2.1 *$ & $7.0 \pm 1.4 \mathrm{~B}$ & $7.8 \pm 2.9$ & $10.0 \pm 3.6 \mathrm{~A} *$ & $7.3 \pm 3.2$ & $7.5 \pm 2.6 \mathrm{AB}$ \\
& 2018 & $4.5 \pm 1.3$ & $6.8 \pm 2.1 \mathrm{~B}$ & $7.3 \pm 1.7$ & $5.0 \pm 1.4 \mathrm{bB}$ & $9.0 \pm 3.2 \mathrm{a}$ & $5.8 \pm 0.5 \mathrm{abB}$ \\
\hline \multirow{2}{*}{ Annual } & 2015 & $2.0 \pm 1.6 \mathrm{~A}$ & $2.8 \pm 0.9 \mathrm{~A}$ & $2.0 \pm 0.8$ & $1.8 \pm 0.5$ & $2.8 \pm 0.5 \mathrm{~A}$ & $2.8 \pm 0.9$ \\
grasses & 2016 & $1.3 \pm 0.9 \mathrm{AB}$ & $0.8 \pm 0.5 \mathrm{~B}$ & $1.3 \pm 0.1$ & $0.8 \pm 0.5$ & $1.3 \pm 0.5 \mathrm{~B}$ & $1.3 \pm 0.5$ \\
& 2018 & $0.8 \pm 0.5 \mathrm{~B}$ & $1.5 \pm 0.6 \mathrm{~B}$ & $0.8 \pm 0.9$ & $1.0 \pm 1.2$ & $1.8 \pm 1.3 \mathrm{AB}$ & $2.0 \pm 1.4$ \\
\hline \multirow{2}{*}{ Total } & 2015 & $12.3 \pm 7.5$ & $16.3 \pm 3.4 \mathrm{~A}$ & $12.5 \pm 3.7$ & $11.5 \pm 2.1 \mathrm{~A}$ & $16.0 \pm 2.2 \mathrm{~A}$ & $13.8 \pm 4.3 \mathrm{~A}$ \\
annuals & 2016 & $6.5 \pm 2.5$ & $7.8 \pm 1.3 \mathrm{~B}$ & $9.0 \pm 3.6$ & $10.8 \pm 3.9 \mathrm{~A}$ & $8.8 \pm 3.3 \mathrm{~B}$ & $8.8 \pm 3.0 \mathrm{AB}$ \\
& 2018 & $5.3 \pm 1.5 \mathrm{~b}$ & $8.3 \pm 2.1 \mathrm{aB}$ & $8.0 \pm 1.4 \mathrm{a}$ & $5.5 \pm 1.7 \mathrm{~B}$ & $10.0 \pm 3.4 \mathrm{AB}$ & $7.0 \pm 0.8 \mathrm{~B}$ \\
\hline \multirow{2}{*}{ Perennial } & 2015 & $3.0 \pm 1.12 \mathrm{~B}$ & $4.3 \pm 2.2$ & $3.5 \pm 1.3$ & $5.5 \pm 3.1$ & $5.0 \pm 1.8$ & $3.0 \pm 1.4 \mathrm{AB}$ \\
forbs & 2016 & $5.5 \pm 1.9 \mathrm{~A}$ & $4.0 \pm 0.8$ & $3.6 \pm 1.7$ & $6.0 \pm 2.2 \mathrm{a}$ & $3.5 \pm 2.1 \mathrm{~b}$ & $2.3 \pm 0.9 \mathrm{bB}$ \\
& 2018 & $5.5 \pm 1.7 \mathrm{~A}$ & $4.0 \pm 1.4$ & $6.3 \pm 1.7$ & $7.0 \pm 1.2$ & $5.3 \pm 3.6$ & $5.3 \pm 1.7 \mathrm{~A}$ \\
\hline \multirow{2}{*}{ Perennial } & 2015 & $0.5 \pm 0.5$ & $1.0 \pm 1.1$ & $1.0 \pm 1.2$ & $0.3 \pm 0.5$ & $0.8 \pm 0.5$ & 0.0 \\
grasses & 2016 & 0.0 & $0.3 \pm 0.5$ & $0.5 \pm 0.5$ & $0.3 \pm 0.5$ & $0.8 \pm 0.5$ & $0.3 \pm 0.5$ \\
& 2018 & $0.3 \pm 0.5$ & $0.5 \pm 0.5$ & $0.5 \pm 0.6$ & $0.25 \pm 0.50$ & $0.5 \pm 0.6$ & $0.3 \pm 0.5$ \\
\hline \multirow{2}{*}{ Shrubs } & 2015 & $2.5 \pm 1.3$ & $0.8 \pm 0.9$ & $1.0 \pm 1.1$ & $2.0 \pm 0.8 \mathrm{a}$ & $0.0 \mathrm{~b}$ & $1.0 \pm 0.8 \mathrm{ab}$ \\
& 2016 & $2.3 \pm 0.6 \mathrm{a}$ & $0.3 \pm 0.5 \mathrm{~b}$ & $1.5 \pm 0.6 \mathrm{a}$ & $2.5 \pm 1.0 \mathrm{a}$ & $0.0 \mathrm{~b}$ & $1.5 \pm 0.6 \mathrm{ab}$ \\
& 2018 & $2.5 \pm 1.3$ & $1.0 \pm 0.8$ & $1.0 \pm 0.8$ & $2.5 \pm 1.3 \mathrm{a}$ & $0.3 \pm 0.5 \mathrm{~b}$ & $1.3 \pm 0.5 \mathrm{ab}$ \\
\hline \multirow{2}{*}{ Total } & 2015 & $5.8 \pm 1.9 \mathrm{~B}$ & $5.5 \pm 2.9$ & $5.0 \pm 1.8$ & $7.8 \pm 4.0$ & $5.8 \pm 2.2$ & $4.0 \pm 1.4$ \\
perennials & 2016 & $7.8 \pm 2.6 \mathrm{~A}$ & $4.5 \pm 0.6$ & $5.3 \pm 2.2$ & $8.8 \pm 3.0 \mathrm{a}$ & $4.3 \pm 2.2 \mathrm{~b}$ & $4.0 \pm 1.2 \mathrm{~b}$ \\
& 2018 & $8.3 \pm 2.9 \mathrm{~A}$ & $5.5 \pm 2.4$ & $7.8 \pm 2.8$ & $9.8 \pm 2.1$ & $6.0 \pm 3.9$ & $6.8 \pm 1.9$ \\
\hline
\end{tabular}

$\mathrm{a} / \mathrm{b}$ indicate significant differences between the depression sides during the same year; $\mathrm{A} / \mathrm{B}$ indicate significant differences between years for the same side, according to Student-Newman-Keuls test. (*) indicates a significant difference between inside and outside cages for the same side and year. Values are means $\pm \operatorname{SD}(\mathrm{n}=4)$ 


\section{Plant density}

Annual and perennial plant densities of inside and outside cages on the east, middle and west sides of the depression during the three years (2015, 2016 and 2018) are shown in Figure 4. The highest annual density was in the outside cages in the middle of the depression during spring 2015 (131.88 plants. $\mathrm{m}^{-2}$ ), and the lowest in the inside cages on the east side during spring $2018\left(7.5\right.$ plants. $\left.\mathrm{m}^{-2}\right)$. For perennial density, the ANOVA showed a significant difference between years (outside cages on the east side: $p<0.05$; between sides, outside cages in 2016: $\mathrm{p}<0.05)$. The interaction of factors was not significant. However, there were significant differences for annual density between inside and outside cages only in the middle of the depression in spring $2016(p<0.05)$. Also, inter-annual significant differences were noted in the middle of the depression in both inside and outside cages on the one hand, and outside cages on the western side on the other hand. The main difference between aspects was found in the outside cages during the three years. No interaction between factors was noted.

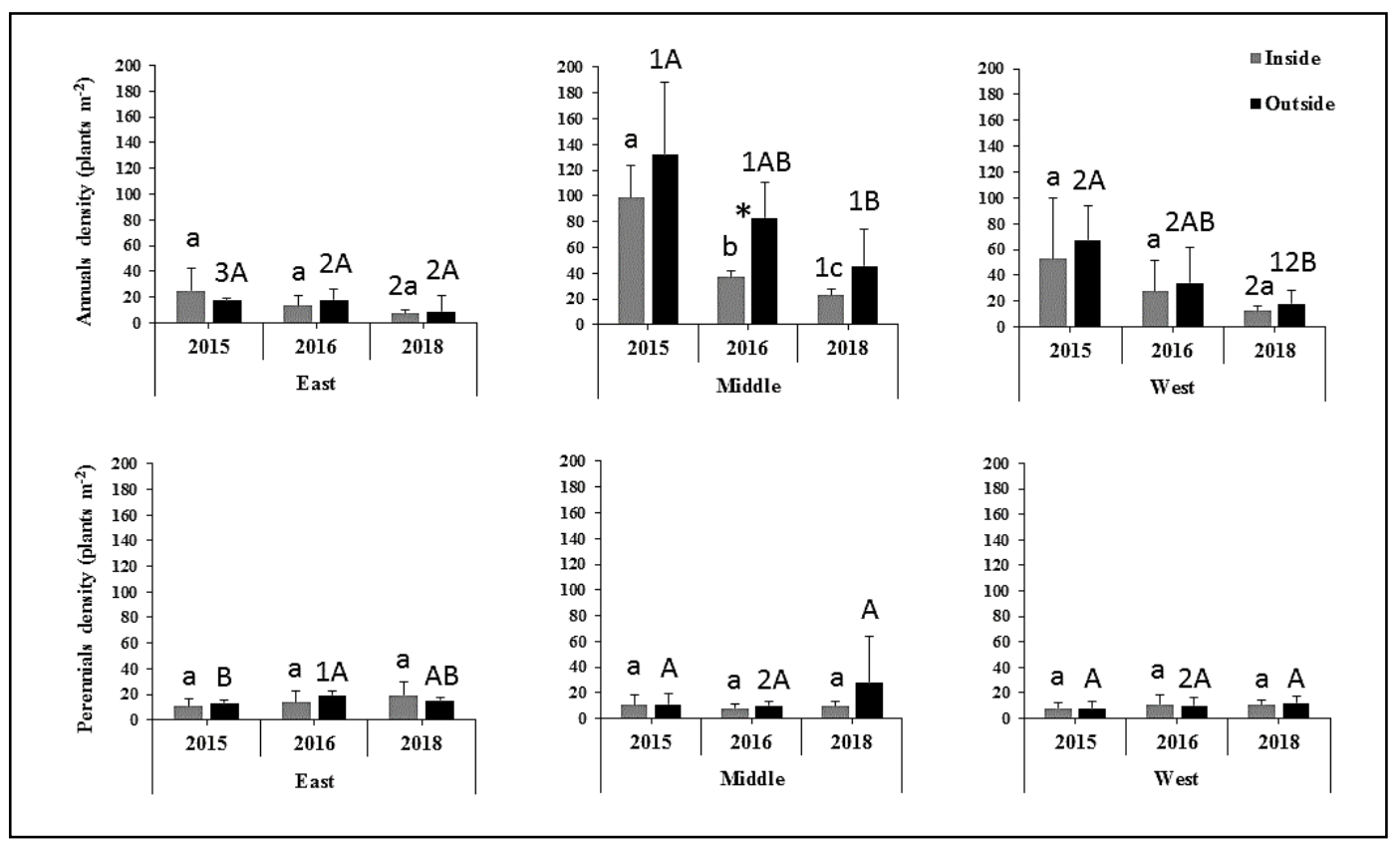

Figure 4. Annual and perennial densities (plant. $m^{-2}$ ) inside and outside cages in the east, the middle and the west side of the Samaliete depression during the spring 2015, 2016 and 2018.

$a / b / c$ and $A / B$ indicate significant differences between years inside and outside cages, respectively, in the same aspect; 1/2/3 indicate significant differences between sides in the same year, according to the Duncan test. (*) indicates significant difference between inside and outside cages for the same side and year; values are means $\pm S D(n=4)$

\section{Diversity}

Jaccard's similarity index between the inside and outside cages is shown in Table 3. The highest index (0.76) was noted between the middle inside (MI1) and outside cages (MO1) in spring 2015, indicating that $76 \%$ of plant species were common to MI1 and MO1. The lowest index (0.17) was between the middle inside cages in spring 2016 (MI2) and eastern outside cages in spring 2018 (EO3). This indicates that the biggest difference in the floristic composition was between MI2 and EO3 (i.e. MI2-EO3). The main results 
of this index indicate floristic homogeneity in the middle of the depression. Some indices exceeded 0.5 , indicating that more than $50 \%$ of plant species were common between the cages. Within the same site, similarity indexes were higher in spring 2015 with $0.63,0.76$ and 0.58 for EI1-EO1, MI1-MO1 and WI1-WO1, respectively. The similarity indices decreased in spring 2016 to 0.48 for EI2-EO2 and MI2-MO2. In spring 2018, similarities were lower with $0.41,0.39$ and 0.52 for EI3-EO3, MI3-MO3 and WI3-WO3, respectively. These results suggest that after three years of fencing, flora diversity had increased in all sites of the depression.

Table 3. Jaccard's similarity index inside and outside cages in the Samaliete depression. The index between inside and outside cages in the same location and year are indicated with bolded numbers

\begin{tabular}{|c|c|c|c|c|c|c|c|c|c|c|c|c|c|c|c|c|c|c|}
\hline & EO1 & EO2 & EO3 & MO1 & MO2 & MO3 & W01 & WO2 & WO3 & EI1 & EI2 & EI3 & MI1 & MI2 & MI3 & WI1 & WI2 & WI3 \\
\hline EO1 & 1.00 & & & & & & & & & & & & & & & & & \\
\hline EO2 & 0.58 & 1.00 & & & & & & & & & & & & & & & & \\
\hline EO3 & 0.48 & 0.49 & 1.00 & & & & & & & & & & & & & & & \\
\hline MO1 & 0.44 & 0.45 & 0.28 & 1.00 & & & & & & & & & & & & & & \\
\hline MO2 & 0.34 & 0.41 & 0.28 & 0.51 & 1.00 & & & & & & & & & & & & & \\
\hline MO3 & 0.36 & 0.31 & 0.36 & 0.48 & 0.41 & 1.00 & & & & & & & & & & & & \\
\hline WO1 & 0.52 & 0.40 & 0.27 & 0.59 & 0.46 & 0.44 & 1.00 & & & & & & & & & & & \\
\hline WO2 & 0.37 & 0.48 & 0.31 & 0.50 & 0.67 & 0.37 & 0.56 & 1.00 & & & & & & & & & & \\
\hline WO3 & 0.45 & 0.36 & 0.43 & 0.42 & 0.37 & 0.58 & 0.51 & 0.44 & 1.00 & & & & & & & & & \\
\hline EI1 & 0.63 & 0.44 & 0.32 & 0.52 & 0.36 & 0.40 & 0.62 & 0.42 & 0.48 & 1.00 & & & & & & & & \\
\hline EI2 & 0.50 & 0.48 & 0.34 & 0.40 & 0.43 & 0.28 & 0.42 & 0.46 & 0.37 & 0.49 & 1.00 & & & & & & & \\
\hline EI3 & 0.36 & 0.39 & 0.41 & 0.32 & 0.25 & 0.46 & 0.31 & 0.28 & 0.36 & 0.31 & 0.28 & 1.00 & & & & & & \\
\hline MI1 & 0.48 & 0.43 & 0.32 & 0.76 & 0.49 & 0.43 & 0.60 & 0.51 & 0.40 & 0.60 & 0.48 & 0.35 & 1.00 & & & & & \\
\hline MI2 & 0.28 & 0.34 & 0.17 & 0.48 & 0.48 & 0.28 & 0.36 & 0.52 & 0.30 & 0.33 & 0.52 & 0.25 & 0.49 & 1.00 & & & & \\
\hline MI3 & 0.31 & 0.31 & 0.39 & 0.31 & 0.25 & 0.39 & 0.25 & 0.28 & 0.36 & 0.29 & 0.28 & 0.46 & 0.35 & 0.28 & 1.00 & & & \\
\hline WI1 & 0.67 & 0.50 & 0.40 & 0.59 & 0.46 & 0.47 & 0.58 & 0.53 & 0.51 & 0.62 & 0.53 & 0.35 & 0.60 & 0.39 & 0.35 & 1.00 & & \\
\hline WI2 & 0.50 & 0.55 & 0.35 & 0.50 & 0.51 & 0.35 & 0.46 & 0.58 & 0.41 & 0.49 & 0.68 & 0.33 & 0.51 & 0.61 & 0.29 & 0.64 & 1.00 & \\
\hline WI3 & 0.47 & 0.45 & 0.51 & 0.44 & 0.35 & 0.54 & 0.40 & 0.35 & 0.52 & 0.40 & 0.35 & 0.54 & 0.45 & 0.29 & 0.45 & 0.49 & 0.41 & 1.00 \\
\hline
\end{tabular}

EO, east outside; MO, middle outside; WO, west outside; EI, east inside; MI, middle inside; and WI, west inside. 1, 2 and 3 correspond to years 2015, 2016 and 2018, respectively

\section{Productivity and economic evaluation}

Rangeland production of the grazed area in the Samaliete depression significantly differed $(p<0.05)$ between the rainy (2015) and dry (2016) years, with $172.42 \pm 79.99$ and $91.34 \pm 41.67 \mathrm{FU} \mathrm{ha}^{-1} \mathrm{year}^{-1}$, respectively. The lowland systems showed differences among the four farms in terms of economic performance and EPP, but also in terms of farming system (grazing-only and integrated grazing and cropping; Table 4). Farm 4 showed the largest rainfed crop income per hectare (141 EUR/ha), followed by farm 2 (10 EUR/ha). The other two small and medium farms (1 and 3) had negative values of -213 and -6 EUR/ha. However, farm 1 followed farm 4 in terms of EPP.

The diversification of crops (barley, wheat and lentil) had a positive impact on the income of farms 4 and 2. This observation did not apply to farm 3, possibly due to the high cost of paid labor on this farm, used especially for harvesting. The land capital also played an important economic role wherein farm 4 ( 9 ha) had the largest crop income 
(565 EUR, 141 EUR/ha). However, farm 3 had a much lower income ( 3 ha and $-6 \mathrm{EUR} / \mathrm{ha}$ ) than farm 2 ( 1 ha and $10 \mathrm{EUR} / \mathrm{ha}$ ).

Table 4. Characterization and differences in term of economic performance and efficiency of the production process between the four landscape depression farm) in the Samaliete region

\begin{tabular}{|c|c|c|c|c|}
\hline Total area (ha) & $\begin{array}{c}\text { Farm } 1 \\
1\end{array}$ & $\begin{array}{c}\text { Farm } 2 \\
1\end{array}$ & $\begin{array}{c}\text { Farm } 3 \\
3\end{array}$ & $\begin{array}{c}\text { Farm } 4 \\
9\end{array}$ \\
\hline Farming system (rainy year) & Wheat & Wheat + lentil & $\begin{array}{c}\text { Wheat + barley } \\
+ \text { lentil }\end{array}$ & $\begin{array}{c}\text { Wheat + barley } \\
+ \text { lentil }\end{array}$ \\
\hline Cropped area (wheat and barley) (ha) & 0.35 & 0.35 & 1 & 3 \\
\hline Cropped area (lentil) (ha) & 0.1 & 0.1 & 0.35 & 1 \\
\hline Grazing area (ha) & 0.55 & 0.55 & 1.65 & 5 \\
\hline Inputs (EUR) & 17 & 34 & 92 & 207 \\
\hline Labor costs (EUR) & 82 & 88 & 252 & 405 \\
\hline Total costs (EUR) & 99 & 122 & 344 & 614 \\
\hline Total costs (EUR /ha) & 220 & 271 & 255 & 154 \\
\hline Total crop gross product (EUR) & 70 & 126 & 336 & 1179 \\
\hline Total crop gross product (EUR /ha) & 155 & 281 & 248 & 295 \\
\hline Crop income (EUR) (rainy year) & -29 & 5 & -8 & 565 \\
\hline Crop income (EUR /ha) (rainy year) & -65 & 10 & -6 & 141 \\
\hline $\begin{array}{l}\text { Grazing income (if with crops) (rainy year) } \\
\text { (EUR) }\end{array}$ & 13 & 13 & 39 & 118 \\
\hline $\begin{array}{l}\text { Grazing income (if grazing only) (rainy year) } \\
\text { (EUR) }\end{array}$ & 24 & 24 & 71 & 213 \\
\hline Grazing income (EUR) (dry year) & 12 & 12 & 37 & 112 \\
\hline $\begin{array}{l}\text { Total income (crop and grazing) (1 rainy year) } \\
\text { (EUR) }\end{array}$ & -16 & 18 & 31 & 683 \\
\hline Total income (crop and grazing) (4 years) (EUR) & 21 & 55 & 143 & 1018 \\
\hline Total income (grazing only) (4 years) (EUR) & 61 & 61 & 183 & 548 \\
\hline Profit of grazing only (4 years) (EUR) & 40 & 6 & 40 & -470 \\
\hline $\begin{array}{l}\text { Efficiency of the production process }(\%) \text { (gross } \\
\text { product-inputs/gross product) }\end{array}$ & 75 & 73 & 72 & 82 \\
\hline
\end{tabular}

\section{Discussion}

Overall, human population increase has generated unsustainable land use practices by destroying the natural balance and transforming pastures to crop-livestock systems (Tomlinson et al., 2002; Sanderson et al., 2013). These transformations vary according to social, climatic, edaphic and ecologic aspects. Lowland depressions in arid and semi-arid areas are natural spaces that have undergone remarkable management changes. These landscape depressions constitute valuable areas for agriculture due to their hydrologic characteristics and soil fertility (Louhaichi et al., 2012; Hassan et al., 2017).

Our results showed that flora richness increased following fencing, with a dominance of annuals. Perennials had lower numbers in the middle of the depression, attesting to the negative effect of plowing. In the outside cages, the most common annual species in all depression sides during the three years were Anacyclus cyrtolepidiodes Pomel., Asphodelus tenuifolius Cav., Echium humile Desf., Fagonia glutinosa Del., Filago germanica L., Plantago ovata Forssk. and Schismus barbatus (L.) Thell. The common perennial plants were Argyrolobium uniflorum (Decne.) Jaub. \& Spach, Deverra tortuosa (Desf.) DC., Erodium glaucophyllum (L.) L'Hér., Helianthemum sessiliflorum (Desf.) Pers, Herniaria fontanesii J. Gay and Linaria aegyptiaca (L.) Dum. Cours. Inside cages, 
the most found species (more than 75\%) were Anthyllis henoniana Coss. Ex Batt., Cynodon dactylon (L.) Pers., Gymnocarpos decander Forssk., Helianthemum kahiricum (Delile), Hippocrepis bicontorta Loisel and Reaumuria vermiculata (L.).

The majority of perennial species in the outside cages were unpalatable or of low palatability and only occasionally palatable. The dominant species in the inside cages were palatable and very palatable perennial plants. After short-term fencing (3 years), unpalatable perennials were frequent in the outside cages, but in the inside cages there were increases in palatable and very palatable perennial species.

Comparable studies stated that overgrazing can influence vegetation structure, reducing perennial species richness, especially by losing the most palatable ones, usually replaced by unpalatable and annual species (Noy-Meir, 1995; Peer et al., 2001; Louhaichi et al., 2009, 2012; Tarhouni et al., 2010). Decreasing richness reduces the regeneration ability of rangelands and their resilience capacity by reducing seed production (Louhaichi et al., 2012). Bochet (2015) suggested that, in arid and semi-arid patchy ecosystems, plant seeds can be transported by surface runoff and reach more favorable sites for installation. Lowland depressions can be a suitable refuge area for seed germination and plant growth. However, this opportunity can be lost if depression areas are overgrazed and continuously plowed during rainy years.

Fencing had no effect on perennial plant density, but annual density increased in the middle. This can likely be explained by the abundance of unpalatable perennials in the outside cages, with the regeneration of palatable species in the protected cages or by the plowing effects favoring annual plants. These results corroborate the findings of Louhaichi et al. (2012) concerning the increase of plant density with fencing followed by an increase in annual forbs and grasses with a lower degree of perennial shrubs and semishrubs. Hassan et al. (2017) also reported that plant density increased in protected areas in arid lowland pastures with a dominance of annuals from three main botanical families: Poaceae, Asteraceae and Brassicaceae. Generally, ecosystem regeneration takes time depending on rainfall, seed bank, seed sources, competition between species, severity of disturbance and grazing regime (Pakeman and Small, 2005).

Similarly, species diversity increased greatly following short-term fencing in the middle and on the eastern side of the depression, with less increase evident on the western side. The diversity restitution in the middle is explained by the favorable conditions with good water status without grazing. Low diversity in the east and west sides can be explained by factors such as runoff (decreasing the soil moisture) and sun radiation (Louhaichi et al., 2012; Hassan et al., 2017). Plant diversity is considered the best indicator of health and resilience capacity of ecosystems. Without grazing, plant community recovery depends on precipitation, soil fertility and vegetation composition and physiognomy of woody or herbaceous species (Zhang, 1998). At low soil fertility, high annual species diversity was observed in protected Mongolian grasslands (Gough and Marrs, 1990).

This study shows that short-term fencing with at least one rainy year on arid landscape depressions can improve rangeland productivity by avoiding the negative impact of overgrazing. Nevertheless, grazing intensity is not the only factor determining the profitability of these agro-pastoral systems, and farm size and crop type are also influential. Farm size and stocking rate are among the main factors affecting the adoption of environmental policies and crop-livestock management (Shideed et al., 2007). Consequently, effects of size and crop type on farm economic performance were studied, and an economic evaluation was applied. 
The comparison of economic efficiency of land allocation between the studies depression suggests that g-razing only (non-fenced and non-cropped rangelands) in a 4year period ( 3 years dry and 1 rainy year) is more profitable than integrating grazing with crops (non-fenced and cropped rangelands) on small and medium farms. In the case of large plowed areas, integrating grazing and crops is more economically efficient, especially with crop diversification. In addition to these economic impacts, the association between livestock husbandry and crop production could be considered as a form of response to climatic and socio-environmental risks and uncertainties in southern Mediterranean arid regions (Sraïri et al., 2017). In this case, we have to take into account the possible negative impact of plowing on sustainability of rangelands.

Special attention should be given to the most profitable farms to increase their economic performance and promote their sustainability. Attention should also be given to promoting and consolidating the productive choices that demonstrate their effectiveness, especially in small and medium lowlands, to produce diversified crops with high added value. The aim is to increase and secure farm income by developing diversified crops with high added value (e.g. vegetables and arboriculture) while modifying the rotation and adoption of new crops and reducing others that are less profitable or extending the cultivated area. The extension of cultivated areas can be done by improving water access through investing in the introduction of drip irrigation (occasionally subsidized by the state). These findings are consistent with previous research showing that crop diversification improves the performance of farming systems, enhances resilience and offers food security to households (Darnhofer et al., 2010; Souissi et al., 2018). The effectiveness of this strategy depends on the availability of farm assets, particularly wells, tractors, finance and family labor.

\section{Conclusion}

This study was carried out to investigate the vegetation composition and structure after fencing and to compare the incomes of management types (grazing-only and cropping with continuous grazing) in arid lowland depressions. The overall goal is the promotion of better pastoral, livestock and cropping management to meet population needs while protecting critical ecosystems. Results suggest that short-term fencing improved vegetation structure and pastoral productivity. Using landscape depressions as non-fenced rangelands (grazingonly) is more profitable than integrating grazing with cropping in small and medium areas, while integrated management (grazing with large-area cropping), especially with crop diversification, appeared to be more profitable than grazing-only. In summary, the better use of landscape lowlands in arid areas, having a high productivity compared to highlands, requires consideration of grazing intensity, minimum profitable plowing area and crop diversification. Fencing on sloping sides of depressions increased their fodder production. Protection of some lowland areas could enhance biodiversity. These recommendations are meant to inform decision making in rangeland management projects in arid lands around the world. In future works, the evaluation of carbon sequestration in lowlands could help inform climate change mitigation and adaptation measures.

Acknowledgements. This work was supported by the Arid Regions Institute of Médenine (IRA, Tunisia) budget, the International Center for Agricultural Research in the Dry Areas (ICARDA, Tunis), the OPEC fund for international development (OFID) and the CGIAR Research Program on Livestock (CRP Livestock). Authors acknowledge Scriptoria for English editing and anonymous reviewers for their valuable suggestions. 


\section{REFERENCES}

[1] Aïdoud, A., Le Floc'h, E., Le Houérou, H. N. (2006): Les steppes arides du nord de l'Afrique. - Sécheresse 17(1): 19-30.

[2] Aïdoud, A., Nedjraoui, D., Djebaili, S., Poissonet, J. (1983): Evaluation des ressources pastorales dans les hautes plaines steppiques du Sud Oranais: Productivité et valeur pastorale des parcours. - Bulletin de la Société d'histoire naturelle de l'Afrique du nord 13: 33-46.

[3] Alcamo, J. (2003): Ecosystems and Human Well-Being: A Framework for Assessment. A Report of the Conceptual Framework Working Group of the Millennium Ecosystem Assessment. - Island Press, Washington, DC.

[4] Ayeb, N., Seddik, M., Atti, N., Atigui, M., Fguiri, I., Barmat, A., Arroum, S., Addis, M., Hammadi, M., Khorchani, T. (2016): Growth, feed intake and carcass characteristics of indigenous goats fed local resources in Tunisian arid land. - Animal Production Science 56(11): 1842-1848.

[5] Bochet, E. (2015): The fate of seeds in the soil: a review of the influence of overland flow on seed removal and its consequences for the vegetation of arid and semiarid patchy ecosystems. - Soil 1(1): 131-146.

[6] Carmona, C. P., Röder, A., Azcárate, F. M., Peco, B. (2013): Grazing management or physiography? Factors controlling vegetation recovery in Mediterranean grasslands. Ecological Modelling 251: 73-84.

[7] Daget, P., Poissonet, J. (1971): Une méthode d'analyse phytologique des prairies. Critères d'application. - Annales Agronomiques 22(1): 5-41.

[8] Darnhofer, I., Bellon, S., Dedieu, B., Milestad, R. (2010): Adaptiveness to enhance the sustainability of farming systems. A review. - Agronomy for Sustainable Development 30(3): 545-555.

[9] Eskandari, H., Borji, M., Khosravi, H., Mesbahzadeh, T. (2016): Desertification of forest, range and desert in Tehran province, affected by climate change. - Solid Earth 7(3): 905915.

[10] FAO. (2006): Livestock's Long Shadow. Environmental Issues and Options. - In: Steinfeld, H., Gerber, P., Wassenaar, T., Castel, V., Rosales, M., de Haan, C. (eds.) FAO, LEAD initiative. FAO: Rome, Italy.

[11] Floret, Ch. (1988): Méthodes de Mesure de la Végétation Pastorale. Pastoralisme et Développement. - CIHEAM: Montpellier Cedex.

[12] Gamoun, M., Werner, J., Louhaichi, M. (2018): Traditional grazing-management practice makes an impact in southern Tunisia. - Retrieved from: http://www.icarda.org/dryWire/traditional-grazing-management-practice-makes-impactsouthern-tunisia. (Accessed, 27 October 2020).

[13] Gough, M. W., Marrs, R. H. (1990): A comparison of soil fertility between semi-natural and agricultural plant communities: Implications for the creations of species-rich grassland on abandoned agricultural land. - Biological Conservation 51(2): 83-96.

[14] Grimm, N. B., Chapin III, F. S., Bierwagen, B., Gonzalez, P., Groffman, P. M., Luo, Y., Melton, F., Nadelhoffer, K., Pairis, A., Raymond, P. A., Schimel, J., Williamson, C. E. (2013): The impacts of climate change on ecosystem structure and function. - Frontiers in Ecology and Environment 11(9): 474-482.

[15] Hassan, S., Ates, S., Kaabneh, A., Louhaichi, M. (2017): The effect of grazing exclusion on vegetation characteristics and plant community structure in arid lowland pastures. Retrieved from: http://om.ciheam.org/om/pdf/a114/00007551.pdf. (Accessed, 27 october 2020).

[16] Hoffmann, I., From, T., Boerma, D. (2014): Ecosystem services provided by livestock species and breeds, with special consideration to the contributions of small-scale livestock keepers and pastoralists. - Rome: FAO. Retrieved from: http://www.fao.org/3/aat598e.pdf. (Accessed, 27 october 2020). 
[17] Hubbell, S. P., Foster, R. B., O'Brien, S. T., Harms, K. E., Condit, R., Wechsler, B., Wright, S. J., De Lao, S. L. (1999): Light-cap disturbances, recruitment limitation, and tree diversity in a neotropical forest. - Science 283(5401): 554-557.

[18] Lal, R. (2002): Carbon sequestration in dryland ecosystems of west Asia and North Africa. - Land Degradation \& Development 13(1): 45-59.

[19] Le Houérou, H. N., Ionesco, T. (1973): Palatabilité des espèces végétales de la Tunisie steppique (indices spécifiques). - Project FAO/TUN - 71/525. Rome: FAO, Division Production et Protection des Plantes.

[20] Louhaichi, M., Salkini, A. K., Petersen, S. L. (2009): Effect of small ruminant grazing on the plant community characteristics of semi-arid Mediterranean ecosystems. - International Journal of Agriculture and Biology 11(6): 681-689.

[21] Louhaichi, M., Ghassali, F., Salkini, A. K., Petersen, S. L. (2012): Effect of sheep grazing on rangeland plant communities: case study of landscape depressions within Syrian arid steppes. - Journal of Arid Environments 79: 101-106.

[22] Nefzaoui, A., El Mourid, M. (2008): Rangeland Improvement and Management in Arid and Semi-Arid Environments of West Asia and North Africa. - Cairo: ICARDA. http://hdl.handle.net/10625/44380.

[23] Noy-Meir, I. (1995): Interactive effects of fire and grazing on structure and diversity of Mediterranean grasslands. - Journal of Vegetation Science 6(5): 701-710.

[24] Ouessar, M., Tâamallah, H., Ouled Begacem, A. (2006): Un environnement soumis à des fortes contraintes climatiques. - In: Genin, D., Guillaume, H., Ouessar, M., OuledBelgacem, A., Romagny, B., Sghaier, M., Taamallah, H. (eds.) Entre désertification et développement: La Jeffara tunisienne. Cérès éditions, Tunis (Tunisie), pp.23-32.

[25] Ouled-Belgacem, A. (2012): Rangeland resting. - In: Schwilch, G., Hessel, R., Verzandvoort, S. (eds.) Desire for Greener Land. Options for sustainable land management in drylands. Bern, Switzerland, and Wageningen, The Netherlands: University of Bern CDE, Alterra - Wageningen UR, ISRIC - World Soil Information and CTA - Technical Centre for Agricultural and Rural Cooperation, pp.169-172.

[26] Ouled-Belgacem, A. (2018): Rangeland restoration and management in relation to land tenure and vegetation type: the revival of the resting " $g d e l$ " technique in southern Tunisia. - ICARDA Technical Report. https://hdl.handle.net/20.500.11766/8276. (Accessed, 27 october 2020).

[27] Ouled-Belgacem, A., Tarhouni, M., Louhaichi, M. (2013): Effect of protection on plant community dynamics in the Mediterranean arid zone of southern Tunisia: a case study from Bou Hedma National Park. - Land Degradation \& Development 24(1): 57-62.

[28] Pakeman, R. J., Small, J. L. (2005): The role of the seed bank, seed rain and the timing of disturbance in gap regeneration. - Journal of Vegetation Science 16(1): 121-130.

[29] Peer, T., Millinger, A., Gruber, J. P., Hussain, F. (2001): Vegetation and altitudinal zonation in relation to the impact of grazing in the steppe lands of the Hindu Kush Range (N-Pakistan). - Phytocoenologia 31(4): 477-498.

[30] Reynolds, J. F., Smith, D. M., Lambin, E. F., Turner, B. L., Mortimore, M., Batterbury, S. P., Downing, T. E., Dowlatabadi, H., Fernandez, R. J., Herrick, J. E., Sannwald, E. H., Jiang, H., Leemans, R., Lynam, T., Maestre, F. T., Ayarza, M., Walker, B. (2007): Global desertification: building a science for dryland development. - Science 316(5826): 847-851.

[31] Roux, G., Roux, M. (1967): À propos de quelques méthodes de classification en phytosociologie. - Revue de Statistique Appliquée 15(2): 59-72.

[32] Sanderson, M. A., Archer, D., Hendrickson, J., Kronberg, S., Liebig, M., Nichols, K., Schmer, M., Tanaka, D., Aguilar, J. (2013): Diversification and ecosystem services for conservation agriculture: Outcomes from pastures and integrated crop-livestock systems. - Renewable Agriculture and Food Systems 28(2): 129-144.

[33] Schilling, J., Freier, K. P., Hertig, E., Scheffran, J. (2012): Climate change, vulnerability and adaptation in North Africa with focus on Morocco. - Agriculture Ecosystems \& Environment 156: 12-26. 
[34] Shideed, K., El Mourid, M., Alary, V., Laamari, A., Nefzaoui, A. (2007): Enabling policy environment to enhance uptake of natural resources management technologies in marginal drylands: empirical evidence from Morocco and Tunisia. - In: King, C., Bigas, H., Zafar, A. (eds.) Proceedings of the Joint International Conference "Desertification and the International Policy Imperative". Algiers (Algeria) 17-19 December 2006, pp.201-212.

[35] Slimani, H., Aïdoud, A. (2004): Desertification in the Maghreb: a case study of an Algerian high-plain steppe. - In: Marquina, A. (ed.) Environmental Challenges in the Mediterranean 2000-2050. NATO Science Series 37: 93-108.

[36] Souissi, I., Boisson, J. M., Mekki, I., Therond, O., Flichman, G., Wery, J., Belhouchette, H. (2018): Impact assessment of climate change on farming systems in the South Mediterranean area: A Tunisian case study. - Regional Environmental Change 18(3): 637650.

[37] Squires, V. R., Lu, X., Lu, Q., Wang, T., Yang, Y. (2009): Degradation and Recovery in China's Pastoral Lands. - CABI, Wallingford, UK.

[38] Sraïri, M. T., M'ghar, F. A., Benidir, M., Bengoumi, M. (2017): Analyse typologique de la diversité et des performances de l'élevage oasien. - Cahiers Agricultures 26(1): 15005.

[39] Tarhouni, M., Ben Salem, F., Belgacem, A. O., Neffati, M. (2010): Acceptability of plant species along grazing gradients around watering points in Tunisian arid zone. - Flora 205(7): 454-461.

[40] Temel, S., Surmen, M., Tan, M. (2015): Effects of growth stages on the nutritive value of specific halophyte species in saline grasslands. - Journal of Animal and Plant Sciences 25(5): 1419-1428.

[41] Tietjen, B., Jeltsch, F. (2007): Semi-arid grazing systems and climate change: a survey of present modelling potential and future needs. - Journal of Applied Ecology 44(2): 425-434.

[42] Tlili, A., Tarhouni, M., Cerdà, A., Louhaichi, M., Neffati, M. (2018): Comparing yield and growth characteristics of four pastoral plant species under two salinity soil levels. - Land Degradation \& Development 29(9): 3104-3111.

[43] Tomlinson, K. W., Hearne, J. W., Alexander, R. R. (2002): An approach to evaluate the effect of property size on land-use options in semi-arid rangelands. - Ecological Modelling 149(1-2): 85-95.

[44] VijayaVenkataRaman, S., Iniyan, S., Goic, R. (2012): A review of climate change, mitigation and adaptation. - Renewable \& Sustainable Energy Reviews 16(1): 878-897.

[45] Zhang, M., Wu, J., Tang, Y. (2016): The effects of grazing on the spatial pattern of elm (Ulmus pumila L.) in the sparse woodland steppe of Horqin Sandy Land in northeastern China. - Solid Earth 7(2): 631-637.

[46] Zhang, W. (1998): Changes in species diversity and canopy cover in steppe vegetation in Inner Mongolia under protection from grazing. - Biodiversity and Conservation 7(10): $1365-1381$. 